\title{
RESILIENSI \\ PERAWAT YANG BEKERJA DI UNIT GAWAT DARURAT (UGD) RUMAH SAKIT AL ISLAM (RSAI) BANDUNG
}

\author{
ANDRIA PRAGHOLAPATI \\ Prodi Keperawatan, FPOK, Universitas Pendidikan Indonesia \\ Andria.pragholapati@upi.edu
}

\begin{abstract}
Introduction: Individuals themselves actually have the ability to be able to adjust to a high and flexible when faced with internal and external pressure, known as resilience. The purpose of this study was to determine the description of the resilience of nurses working in the Emergency Unit (UGD) of Al Islam Hospital (RSAI) in Bandung.

Method: The study was conducted descriptively. Sampling in total sampling so that the samples taken were all nurses in the Emergency Unit of Al Islam Hospital as many as 19 people. To examine resilience, a measurement tool called RAS (Resiliency Attitudes Scale) is used.

Results: The ability of nurses in dealing with difficulties or problems that occur while working or resilience of 19 nurses in the RSAI Bandung emergency room, showed that 11 nurses were at high resilience and as many as 8 nurses were at low resilience.

Suggestion: Create a comfortable work situation or conditions to create a conducive work environment.
\end{abstract}

Keywords: Resilience, Nurses, Emergency Unit

\begin{abstract}
ABSTRAK
Pendahuluan: Individu sendiri ternyata memiliki kemampuan untuk bisa menyesuaikan diri yang tinggi dan luwes saat dihadapkan pada tekanan internal maupun eksternal yang dikenal dengan istilah resiliensi. Tujuan penelitian ini adalah untuk mengetahui gambaran resiliensi perawat yang bekerja di Unit Gawat Darurat (UGD) Rumah Sakit Al Islam (RSAI) Bandung.

Metode: Penelitian dilakukan dengan deskriptif. Pengambilan sampel secara total sampling sehingga sampel yang diambil yaitu seluruh perawat di Unit Gawat Darurat Rumah Sakit Al Islam sebanyak 19 orang. Untuk meneliti resiliensi digunakan alat ukur yang dinamakan RAS (Resiliency Attitudes Scale).

Hasil: Kemampuan perawat dalam menghadapi kesulitan-kesulitan atau masalah yang terjadi saat bekerja atau resiliensi pada 19 perawat UGD RSAI Bandung, menunjukkan bahwa 11 perawat berada pada resiliensi tinggi dan sebanyak 8 perawat berada pada resiliensi rendah.

Saran: Menciptakan situasi atau kondisi kerja yang nyaman agar tercipta lingkungan kerja yang kondusif.
\end{abstract}

Kata kunci : Resiliensi, Perawat, Unit Gawat Darurat

\section{INTRODUCTION}

Individu sendiri ternyata memiliki kemampuan untuk bisa menyesuaikan diri yang tinggi dan luwes saat dihadapkan pada tekanan internal maupun eksternal yang dikenal dengan istilah resiliensi (Block dalam Klohnen, 1996 dalam Chandra 2009). Resiliensi disebut juga oleh Wolin and Wolin (Bautista, Roldan \& Bascal, 2001 dalam Chandra, 2009), sebagai keterampilan koping saat dihadapkan pada 
tantangan hidup atau kapasitas individu untuk tetap sehat (wellness) dan terus memperbaiki diri (self repair). Di sisi lain bahwa resiliensi merupakan kapasitas yang bersifat universal dan dengan kapasitas tersebut, individu, kelompok ataupun komunitas mampu mencegah, meminimalisir ataupun melawan pengaruh yang bisa merusak saat mereka mengalami masalah atau beban hidup (Grotberg, 1995 dalam Chandra, 2009).

Individu yang memiliki resiliensi mampu menghadapi tekanan dan perbedaan dalam lingkungan. Individu yang resilien merupakan individu yang mempunyai intelegensi yang baik, mudah beradaptasi, social temperament, dan berkepribadian yang menarik, yang pada akhirnya memberikan kontribusi secara konsisten pada penghargaan diri sendiri, kompetensi, dan perasaan bahwa ia beruntung (Banaag, 2002). Maka perawat yang resilien memiliki kecenderungan untuk lebih kuat dan tidak mudah jatuh sakit ketika menghadapi tuntutan dan beban kerja.

Stres kerja di lingkup pekerjaan keperawatan akan berbeda tingkatnya, tergantung dari stresor yang ada di unit pekerjaanya dan tanggapan terhadap stresor tersebut. Bila melihat beberapa penelitian, diketahui bahwa tingkat stresor kerja di unit gawat darurat lebih tinggi dibandingkan dengan unit kerja yang lain (Sexton, J.B, 2000 dalam Niven, 2000).

Di rumah sakit, dalam upaya memudahkan pelayanan maka dibentuk unitunit pelayanan yaitu; unit rawat jalan, unit rawat inap, intensive care unit (ICU) dan unit gawat darurat (UGD). Unit kesehatan yang menyelenggarakan pelayanan gawat darurat disebut Unit Gawat Darurat [1], [2]. Unit gawat darurat, merupakan bagian yang sangat penting karena masyarakat meminta pertolongan pertama di unit tersebut secara terus-menerus. Dalam pelayanan gawat darurat dilakukan pelayanan gawat darurat berlangsung selama 24 jam dalam sehari. Pelayanan gawat darurat adalah pelayanan yang diberikan kepada klien yang tiba-tiba berada dalam keadaan gawat atau akan menjadi gawat dan terancam nyawanya atau anggota badannya akan menjadi cacat bila tidak mendapat pertolongan (Depkes, 1995).

Berdasar pada profil Rumah Sakit Al Islam (RSAI) Bandung tahun 2009, RSAI Bandung merupakan rumah sakit yang memiliki kapasitas tempat tidur sebanyak 275 buah. RSAI Bandung memiliki fasilitas Unit Gawat Darurat (UGD).

Unit Gawat Darurat RSAI Bandung mempekerjakan 19 perawat, seluruh perawat di UGD berpendidikan terakhir D3 keperawatan. Jumlah rata-rata kunjungan pasien UGD pada tahun 2009 sebanyak 138 orang per hari dan rata-rata kunjungan perbulan sebanyak 4147 pasien.

Bagian UGD mempunyai tiga shift jam kerja, yaitu shift pagi, shift siang, dan shift malam. Shift pagi dimulai dari jam 07.00 - 14.00, shift siang jam $14.00-$ 21.00, dan shift malam jam 21.00 - 07.00. Di setiap shift perawat di UGD RSAI Bandung tidak diberikan waktu khusus untuk istirahat. Namun karena keterbatasan perawat maka waktu istirahat ini harus disesuaikan dengan situasi dan kondisi, artinya jika ada tindakan yang harus diberikan kepada pasien secara gawat dan darurat maka perawat harus selalu siap untuk melaksanakan tugasnya.

Berdasarkan hasil wawancara dengan Kepala Ruangan Unit Gawat Darurat (UGD) RSAI Bandung, beliau mengatakan bahwa jumlah tenaga perawat di UGD RSAI Bandung masih kurang dari standar, beliau mengatakan idealnya tujuh sampai delapan orang setiap shiftnya sedangkan yang ada sekarang untuk setiap shift-nya, dijaga oleh lima orang perawat. Lalu beliau mengatakan sebelumnya 


\section{Research Article}

sudah ada perawat yang meminta keluar dan untuk bulan sekarang pun akan ada yang keluar dua orang.

Berdasarkan hasil studi pendahuluan yang peneliti lakukan terhadap lima orang perawat yang bekerja di Unit Gawat Darurat (UGD) RSAI Bandung, diketahui beberapa orang perawat menunjukan adanya gejala stres, sebanyak lima orang perawat mengeluhkan pola tidur berubah/tidak teratur, empat orang mengeluhkan pola makan berubah, dua orang merasakan jantung berdebardebar dan berkeringat lebih banyak dari biasanya, dan satu orang mengeluhkan susah tidur dan mudah lelah/letih, tegang di daerah leher dan bahu, pencernaan terganggu, dan merasa pusing. Dalam tiga bulan terakhir yaitu bulan September, Oktober, dan Nopember ditemukan 12 orang yang sakit. Dengan lama hari yang berbeda-beda yaitu tiga orang selama tiga hari, dua orang selama lima hari dan 7 orang selama 12 hari.

Selain itu responden juga menunjukan karakteristik resiliensi yaitu satu orang perawat sulit untuk tertawa, mudah menangis, sulit untuk berkonsentrasi, sulit berpikir jernih, merasa kecewa dan menolak dengan kondisinya saat ini, merasa tidak tahu harus melakukan apa atau memulai dari mana, tidak memiliki target yang harus dicapai saat bekerja dan tidak memiliki seseorang sebagai panutan yang bisa merubah saya ke arah yang lebih baik.

Berdasarkan fenomena di atas, penulis merasa tertarik untuk melakukan penelitian dengan fokus penelitian adalah Mengidentifikasi resiliensi perawat Unit Gawat Darurat (UGD) Rumah Sakit Al Islam (RSAI) Bandung.

\section{Definisi Resiliensi}

Wolin and Wolin (1993) menyatakan bahwa resiliensi adalah proses tetap berjuang saat berhadapan dengan kesulitan, masalah, atau penderitaan. Resiliensi dalam penelitian ini adalah tinggi rendahnya kemampuan perawat dalam menghadapi kesulitan-kesulitan atau masalah yang terjadi saat bekerja di bagian UGD rumah sakit. Data dalam penelitian ini dikumpulkan dengan menggunakan kuesioner yang terdiri dari 72 pertanyaan. Sistem penilaian yang dipakai sesuai dengan metoda skala Likert, dengan lima pilihan jawaban yang telah disediakan untuk setiap item, yaitu : SS (Sangat Setuju), S (Setuju), RR (Ragu-Ragu), TS (Tidak Setuju), STS (Sangat Tidak Setuju). Hasil akhir yang didapat dalam penelitian ini adalah persentase jumlah perawat yang memiliki resiliensi tinggi dan resiliensi rendah.

Resiliensi adalah proses tetap berjuang saat berhadapan dengan kesulitan, masalah, atau penderitaan (Wolin \& Wolin, 1993). Menurut Reivich and Shatte (2002) adalah kemampuan untuk beradaptasi dan tetap teguh dalam situasi sulit. Sedangkan menurut Banaag (2002), menyatakan bahwa resiliensi adalah suatu proses interaksi antara faktor individual dengan faktor lingkungan. Faktor individual ini berfungsi menahan perusakan diri sendiri dan melakukan kontruksi diri secara positif, sedangkan faktor lingkungan berfungsi untuk melindungi individu dan "melunakkan" kesulitan hidup individu.

Sementara itu resiliensi didefinisikan oleh Wolin and Wolin (1999) sebagai proses tetap berjuang saat berhadapan dengan kesulitan, masalah, atau penderitaan. Menurut Gallagher and Ramey (dalam Isaacson, 2002), resiliensi adalah kemampuan untuk pulih secara spontan dari hambatan dan mengkompensasi kekurangan atau kelemahan yang ada pada dirinya. 


\section{Research Article}

\section{METHOD}

\section{Jenis Penelitian}

kuantitatif.

Jenis penelitian yang digunakan dalam penelitian ini adalah deskriptif

\section{Populasi Penelitian}

Populasi dalam penelitian ini adalah semua perawat yang bekerja di ruang unit gawat darurat Rumah Sakit Al Islam Bandung yang berjumlah 19 perawat UGD.

\section{Sampel}

Dalam penelitian ini, sampel diambil dengan cara "Total Sampling" yaitu teknik pengambilan sampel dimana seluruh populasi dijadikan sebagai sampel. Sampel dalam penelitian ini yaitu seluruh perawat yang bekerja di ruang unit gawat darurat Rumah Sakit Al Islam Bandung. Jumlah Sampel dalam penelitian ini adalah 19 perawat UGD.

\section{Teknik Pengumpulan Data}

Untuk mendapatkan data yang sesuai dengan tujuan penelitian, peneliti menggunakan teknik pengumpulan data dengan kuesioner. Kuesioner adalah sejumlah pertanyaan tertulis yang digunakan untuk memperoleh informasi dari responden dalam arti laporan tentang pribadi atau hal-hal yang diketahuinya.

Kuesioner (daftar pertanyaan tertulis) ini diedarkan dan dijelaskan terlebih dahulu oleh peneliti mengenai tatacara pengisian instrumen. Peneliti mendampingi responden dalam mengisi instrumen, sehingga jika responden tidak mengerti maksud pertanyaan, dapat langsung ditanyakan kepada peneliti. Responden hanya diberi peluang untuk memilih salah satu alternatif/kategori jawaban yang telah disediakan oleh peneliti.

\section{Instrumen Penelitian}

Instrumen adalah alat bantu yang digunakan untuk mengumpulkan data. Alat pengumpulan data atau instrumen yang digunakan dalam penelitian ini adalah kuesioner, yaitu sejumlah pertanyaan tertulis yang digunakan untuk memperoleh informasi dari responden dalam arti laporan tentang pribadi atau hal-hal yang diketahuinya.

\section{Resiliensi}

Instrumen yang digunakan untuk meneliti resiliensi pada responden adalah instrumen resiliensi diukur dengan instrumen penelitian Resiliency Attitudes Scale (R.A.S.) yang dibuat oleh Biscoe and Harris (1999) berdasarkan teori resiliensi yang dikemukakan oleh Wolin and Wolin (1993).

\section{Teknik Analisa Data \\ Analisis Univariat \\ Resiliensi}

Untuk menentukan kategori resiliensi perawat di Unit Gawat Darurat (UGD) Rumah Sakit Al Islam (RSAI) Bandung diperoleh dengan cara melihat hasil pengukuran dari skor $\mathrm{T}$.

\section{RESULT}

Penelitian ini dilakukan pada 19 responden yaitu perawat yang bekerja di Unit Gawat Darurat Rumah Sakit Al Islam Bandung. Penelitian ini bertujuan untuk 


\section{Research Article}

mengetahui gambaran resiliensi perawat. Dari hasil penelitian tersebut dilakukan pengategorian terhadap resiliensi. Untuk kategori resiliensi terbagi menjadi

\section{Resiliensi Perawat yang Bekerja di Unit Gawat Darurat (UGD) Rumah Sakit Al Islam Bandung}

Tabel 1 Distribusi Frekuensi Resiliensi Perawat yang Bekerja di Ruang UGD RSAI Bandung

\begin{tabular}{ccc}
\hline Resiliensi & Frekuensi $(\mathbf{F})$ & Persentasi $\mathbf{( \% )}$ \\
\hline Tinggi & 11 & 57,89 \\
Rendah & 8 & 42,11 \\
Total & 19 & 100 \\
\hline Berdasarkan tabel 1 dapat diinterpretasikan, resiliensi tinggi $57,89 \%$, yaitu
\end{tabular}
sebanyak 11 orang dan resiliensi rendah $42,11 \%$, yaitu sebanyak 8 orang.

\section{Karakteristik Responden}

Berdasarkan hasil penelitian terhadap 19 perawat UGD RSAI Bandung, maka dapat dideskripsikan karakteristik responden sebagai berikut:

Tabel 2 Distribusi Frekuensi Karakteristik Responden di Ruang UGD RSAI Bandung, Bulan Januari Tahun 2010

\begin{tabular}{lcc}
\hline \multirow{2}{*}{ Kategori } & \multicolumn{2}{c}{ UGD } \\
\cline { 2 - 3 } & $\begin{array}{c}\text { Frekuensi } \\
(\mathrm{f})\end{array}$ & $\begin{array}{c}\text { Persentase } \\
(\%)\end{array}$ \\
\hline Berdasarkan Jenis Kelamin & & $36,84 \%$ \\
\hline Laki-Laki & 7 & $63,16 \%$ \\
Perempuan & 12 & $0 \%$ \\
\hline Berdasarkan Tingkat Pendidikan & & $100 \%$ \\
\hline SPK & 0 & $0 \%$ \\
D3 & 19 & $21,05 \%$ \\
S1 & 0 & $26,32 \%$ \\
\hline Berdasarkan Lama Kerja & & $52,63 \%$ \\
\hline 0-2 Tahun & 4 & \\
3-5 Tahun & 5 & \\
$>$ 5 Tahun & 10 & \\
\hline
\end{tabular}

Berdasarkan tabel 2 diketahui bahwa lebih dari setengah $(63,16 \%)$ responden yang bekerja di UGD RSAI Bandung berjenis kelamin perempuan. Seluruh responden (100\%) di UGD RSAI Bandung berpendidikan terakhir D3. Lebih dari setengah (52.63\%) responden yang bekerja di UGD RSAI Bandung bekerja lebih dari lima tahun. 


\section{Research Article}

\section{DISCUSSION}

\section{Resiliensi Perawat di UGD RSAI Bandung}

Berdasarkan hasil penelitian terhadap 19 perawat UGD RSAI Bandung, menunjukan bahwa 11 perawat $(57,89 \%)$ berada pada resiliensi tinggi dan sebanyak 8 perawat $(42,11 \%)$ berada pada resiliensi rendah.

Kualitas resiliensi tidak sama pada setiap individu, sebab kualitas resiliensi seseorang sangat ditentukan oleh tingkat usia, taraf perkembangan, intensitas seseorang dalam menghadapi situasi-situasi yang tidak menyenangkan, serta seberapa besar dukungan sosial dalam pembentukan resiliensi seseorang tersebut (Grotberg dalam [2]-[6]

Menurut Masten and Coatswerth (dalam Davis, 1999), mengatakan bahwa untuk mengidentifikasikan resiliensi diperlukan dua syarat, yaitu yang pertama adanya ancaman yang signifikan pada individu (ancaman berupa status high risk atau ditimpa kemalangan dan trauma kronis) dan yang kedua adalah kualitas adaptasi atau perkembangan individu tergolong baik.

Berdasarkan hasil perhitungan didapatkan bahwa sebanyak 11 perawat $(57,89 \%)$ memiliki kemampuan dalam menghadapi kesulitan-kesulitan atau masalah yang terjadi saat bekerja di bagian Unit Gawat Darurat (UGD) rumah sakit. Hal ini berarti perawat mampu berinteraksi dengan baik antara faktor individual dengan faktor lingkungan. Faktor individual ini berfungsi menahan perusakan diri sendiri dan melakukan kontruksi diri secara positif, sedangkan faktor lingkungan berfungsi melindungi individu dan melunakkan kesulitan hidup individu (Bannag, 2002). Ini juga berarti perawat memiliki kualitas adaptasi atau perkembangan individu yang tergolong baik. Seseorang yang memiliki resiliensi tinggi mempunyai keterampilan coping saat dihadapkan pada tantangan hidup atau kapasitas individu untuk tetap sehat (wellness) dan terus memperbaiki diri (self repair).

Seperti yang diungkapakan [1], [3], [14], [6]-[13]seseorang yang resilien akan mampu untuk bertahan dibawah tekanan atau kesedihan dan tidak menunjukkan susana hati yang negatif terus menerus. Apabila resiliensi seseorang itu meningkat, maka akan mampu mengatasi masalah-masalah apapun, mampu untuk meningkatkan potensi-potensi diri, menjadi optimis, muncul keberanian dan kematangan emosi.

Sebanyak 8 perawat $(42,11 \%)$ kurang memiliki kemampuan dalam menghadapi kesulitan-kesulitan atau masalah yang terjadi saat bekerja di bagian Unit Gawat Darurat (UGD) rumah sakit, hal ini berarti individu tidak mampu beradaptasi dengan baik saat menghadapi masalah, mengatasi berbagai hambatan, serta mengembangkan potensi yang dimilikinya secara maksimal. Tidak berjuang dengan baik dalam proses menghadapi kesulitan atau masalah dari lingkungan kerja atau dengan kata lain perawat memiliki resiliensi yang rendah.

\section{SUMMARY}

Kemampuan perawat dalam menghadapi kesulitan-kesulitan atau masalah yang terjadi saat bekerja atau resiliensi pada 19 perawat UGD RSAI Bandung, menunjukkan bahwa 11 perawat berada pada resiliensi tinggi dan sebanyak 8 perawat berada pada resiliensi rendah. Diharapkan memberikan penyegaran atau 


\section{Research Article}

kegiatan yang dapat meningkatkan resiliensi (daya juang) seperti berekreasi atau bertamasya. Menciptakan situasi atau kondisi kerja yang nyaman agar tercipta lingkungan kerja yang kondusif.

\section{REFERENCES}

[1] R. Muliani, A. Pragholapati, and I. P. Lestari, "Jurnal Kesehatan dr . Soebandi Mahasiswa Sarjana Keperawatan Tingkat Akhir,” vol. 8, no. 1, pp. 34-39, 2020.

[2] T. Hadiansyah, A. Pragholapati, and D. P. Aprianto, "Gambaran Stres Kerja Perawat Yang Bekerja di Unit Gawat Darurat," vol. 7, no. 2, pp. 5058, 2019.

[3] A. Pragholapati and F. Munawaroh, "Resiliensi pada lansia," J. Surya Muda, vol. 2, no. 1, pp. 1-8, 2020.

[4] A. Pragholapati, F. Munawaroh, Stik. Jenderal Achmad Yani, and Stik. Bhakti Kencana Bandung, "RESILIENSI PADA LANSIA," ejurnal.ars.ac.id, vol. 2, no. 1, p. 2020.

[5] A. Pragholapati, "RESILIENSI PADA KONDISI WABAH COVID-19," 2020.

[6] A. Pragholapati, F. Munawaroh, Stik. Jenderal Achmad Yani, and Stik. Bhakti Kencana Bandung, "RESILIENSI PADA LANSIA," ojs.stikesmuhkendal.ac.id, vol. 2, no. 1, p. 2020.

[7] A. Pragholapati, "Hubungan masalah kesehatan jiwa dengan strategi koping seseorang yang mengalami perceraian di kota bandung," 2016.

[8] A. Pragholapati and W. Ulfitri, "Gambaran Mekanisme Coping pada Mahasiswa Program Studi Sarjana Keperawatan Tingkat IV yang Sedang Menghadapi Tugas Akhir di Sekolah Tinggi Ilmu Kesehatan X Bandung," Humanit. (Jurnal Psikologi), vol. 3, no. 2, pp. 115-126, 2019.

[9] A. Pragholapati, R. S. Oktapiani, and Efri Widianti, "Pengaruh Brain Gym Terhadap Tingkat Depresi Pada Lansia Di Balai Perlindungan Sosial Tresna Werdha Ciparay Bandung," Sk. keperawatan, vol. 5, no. 2, pp. 128 146, 2019.

[10] A. Pragholapati, U. Padjadaran, and F. Keperawatan, "PERAWAT YANG BEKERJA DI UNIT GAWAT DARURAT ( UGD ) RUMAH SAKIT AL ISLAM ( RSAI ) BANDUNG THE CORRELATION OF RESILIENCY WITH NURSE' S WORK STRESS IN EMERGENCY UNIT RUMAH SAKIT AL ISLAM ( RSAI ) BANDUNG," 2010.

[11] A. Ariani et al., "INFORMATION COMMUNICATION TECHNOLOGY ( ICT ) IN MIDWIFERY EDUCATION ( A REVIEW OF THE

LITERATURE )," vol. 3, no. 1, pp. 2014-2017, 2019.

[12] A. Pragholapati, "COVID-19 IMPACT ON STUDENTS,” pp. 1-6, 2020.

[13] A. Pragholapati, "Self-Efficacy Of Nurses During The Pandemic Covid19," no. May 2020, p. 2020.

[14] A. Pragholapati, "HUBUNGAN BULLYING DENGAN KEMAMPUAN SOSIAL PADA REMAJA DI SMK X KOTA BANDUNG," vol. 9, no. 1, pp. 34-40, 2020.

[15] Banaag, C. G. 2002. Reiliency, street Children, and substance abuse prevention. Prevention Preventif, Nov. 2002, Vol 3. 


\section{Research Article}

[16] Biscoe, B. 1994. Resiliency attitudes scales. Oklahoma: Eagle Ridge Institute. Avaible at: http://myais.fsktm.um.edu.my/5381/1/9.pdf (diakses tanggal 17 Desember 2009).

[17] Chandra, Silvia. 2009. Resiliensi. Avalaible at : http://rumahbelajarpsikologi.com/index2.php?option=com_contentanddo_pdf= 1andid=1 39 (diakses tanggal 10 September 2009)

[18] Davis, N.J. 1999. Resilience \& School Violence Prevention: Researchbased program. National Mental Health Information Center.

[19] Departemen Kesehatan Republik Indonesia. 1995. Pedoman Rujukan Medik. Jakarta : Direktorat jendral Pelayanan Medik

[20] Desmita. 2008. Psikologi Perkembangan. PT. Remaja Rosdakarya Offset. Bandung

[21] Isaacson, Bonnie. Characteristics And Enhancement Of Resiliency In Young People. Avalaible at : http://www.uwstout.edu/lib/thesis/2002/2002isaacsonb.pdf (diakses tanggal 30 September 2009).

[22] Niven N. 2000. Psikologi Kesehatan, Edisi Kedua . Jakarta : EGC.

[23] Reivich, K \& Shatte, A, 2002. The Resilience Factor. New York : Broadway Books.

[24] Steven J. Wolin and Sybil Wolin. 1993. The Resilient Self. New York: Villiard Books. Available at : http://www.projectresilience.com/resself.htm (diakses tanggal 1 Desember 2009). 